\title{
Small Rodent Communities in a Complex of Forest Biotopes
}

\author{
Anna BANACH
}

\begin{abstract}
Banach A., 1987: Small rodent communities in a complex of forest biotopes. Acta theriol., 32, 14: 229-244 [With 4 Tables and 7 Figs.].

The present paper is concerned with the study of the relationship between the structure of a small rodent community and spatial differentiation of the forest vegetation inhabited by it. The study area, in the vicinity of the town of Mikołajki (Mazurian Lake District, Poland), comprised alderwood, pine wood, willow brushwood and ash thicket together with their boundaries. The CMR method was used to collect material - small rodents were captured in six 10-day trapping series, in various seasons from 1977 to 1979. A total of 1515 rodents were caught belonging to the following species: Clethrionomys glareolus, Microtus agrestis, Microtus oeconomus, Microtus arvalis, Apodemus flavicollis, Apodemus agrarius, Mus musculus, Sicista betulina. The species permanently inhabiting the given biotopes and the ones immigrating periodically were then distinguished, according to their places of capture. Two categories of rodents were also distinguished - those using one habitat only (one-habitat) and those using two or more habitats (multihabitat). The major differences between small rodent communities in the biotopes under study resulted from the share of the respective species in a given biotope, i.e. its position in the dominance structure and the length of time spent in the biotope. The study has revealed that diverse biotopes neighbouring in the same area account for enrichment if species composition in small rodent communities. The share of species immigrating seasonally from other biotopes depended on population density and the position of Clethrionomys glareolus, the species resident permanently throughout the study area, in the dominance structure.

[Warsaw University, Institute of Zoology, Department of Zoology and Ecology, Krakowskie Przedmieście 26/28, 00-927 Warsaw, Poland].
\end{abstract}

\section{INTRODUCTION}

The spatial distribution and organization of animal populations are influenced by the patchiness of the natural environment. Patchily distributed biotopes provide either better or worse conditions for various animal populations to settle in and proliferate (i.e. increase their number as a result of natural growth), according to their biotope preferences. Differences between species population densities in various biotopes display the importance of biotope favourability (Aulak, 1970; Banach et al., 1980; Mazurkiewicz, 1984; and others). It is generally assumed that the favourability of a biotope for a population decreases with the increase of the animal density, resulting, for instance, in seasonal animal 
dispersal to suboptimal biotopes (Goertz, 1964; Fretwell \& Lucas, 1969; Anderson, 1970; Fretwell, 1972; Rottenbery \& Wiens, 1976; Hansson, 1977a, 1977b, 1979; and others). Therefore in different, as regards quality, biotopes of a patchy environment small rodent communities may differ not only in their specific composition, but also in the share of given species in the community, the durability of the community structure, the degree of attachment of respective species to the biotope etc. The differences may then concern the features depndent on environmental factors both of intra- and interpopulation nature.

The present work aims at the evaluation of influence of a mosaic of forest habitats -4 different biotopes, adjoining each other - on the structure of small rodent communities in each of the biotopes, and on the exploitation pattern of such an environment by small rodents.

\section{STUDY AREA, METHODS AND MATERIAL}

The research was carried out in the Mazurian Lake District, North-Eastern Poland. The study area, in the vicinity of Lake Sniardwy, was part of a bigger (ca. 3000 ha) forest complex. The area comprised 4 different, adjoining forest biotopes (Fig. 1), altogether 7.17 ha.

In the immediate vicinity of Lake Sniardwy there was a willow brushwood (with Salicetum pentandro-cinereae phytocenosis in fragmentary form), its undergrowth featuring a large share of the Phragmitetea class. The size of this biotope shrank from 1.8 to 0.94 ha due to the water level change in the Lake, in the spring of 1979 .

The willow brushwood had common boundaries with a pine wood, an alderwood and an ash thicket lying in the middle. The pine wood -2.27 ha - was part of a heterogenous forest complex, several hundred hectares in area, with pine aged 80 years approximately, Querco-Fagetea brushwood, and Molinio-Arrhenatheretea and Vaccinio-Piceetea in the herb layer. The alderwood, with an area of 3.10 ha, was an 80 -meter wide stretch of forest complex with alder aged 40 years approximately, its herb layer featuring a large share of the Molinio-Arrhenatheretea class, and brushwood with the Querco-Fagetea class. The ash thicket, 0.18 ha, comprised marshy Querco-Fagetea shrubs, with ash aged 10 years approximately. Its herb layer displayed a considerable admixture of Molinio-Arrhenatheretea species. There was also a glade in the immediate vicinity of those biotopes.

The research was carried out from summer 1977 till spring 1979 inclusive. Animals were captured in live traps during 10 days in each of the seasons: spring (April), summer (July), and autumn. (September-October) - six study periods altogether.

Live traps were evenly set at $15 \times 15 \mathrm{~m}$ distances over the entire study area, one trap per each permanent trap site. The traps, baited with oats, were inspected twice daily, in the morning and in the evening. Specimens collected by livetraping (CMR method) were identified to species, sexed and numbered, these data were then recorded together with the date and place of capture. 
The Student $t$-test was used to calculate the statistic significance of differences between mean values (variance equality evaluated by Fisher $F$-test). Statistic s.gnificance of differences between proportions was estimated at $p=0.05$, the significance of the coefficient of correlation checked at $p=0.05$.

In the two years of research a total of 1515 rodents belonging to 8 species were recorded in the study area. The species in question were as follows: Clethrionomys glareolus (Schreber, 1780), Microtus agrestis (Linnaeus, 1761), Microtus oeconomus

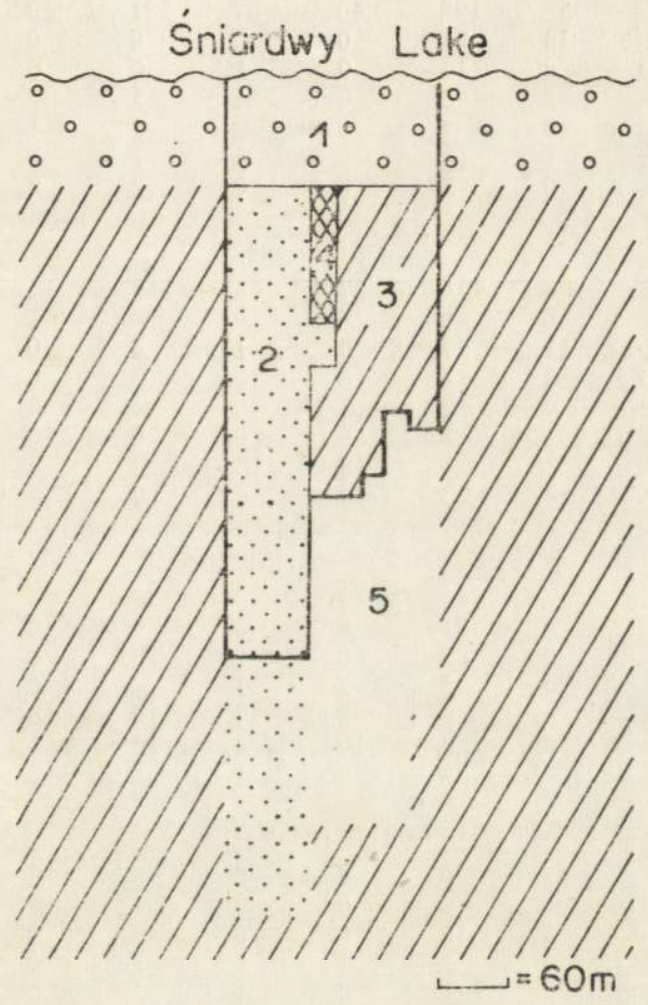

Fig. 1. Diagram of the study area (marked with a heavy line) in the immediate vicinity of Lake Sniardwy. 1 - willow brushwood, 2 - alderwood, 3 - pine wood, 4 - ash thicket, 5 - glade.

(Pallas, 1776), Microtus arvalis (Pallas, 1779), Apodemus flavicollis (Melchior, 1834), Apodemus agrarius (Pallas, 1771), Mus musculus (Linnaeus, 1758), Sicista betulina (Pallas, 1776) (Table 1).

Three insectivorous species were"also noted - Sorex minutus (Linnaeus, 1766), Sorex araneus (Linnaeus, 1758), and Neomys fodiens (Pennant, 1771). Because the live traps used in the research were not suitable for catching Insectivora (Pucek, 1969), the data concerning these species were not analysed. 
Table 1

Particular species numbers and female to male number ratios in small rodent communities in various biotopes. Sp - spring, S summer, A - autumn

\begin{tabular}{|c|c|c|c|c|c|c|c|}
\hline \multirow{2}{*}{ Species } & \multicolumn{2}{|c|}{1977} & \multicolumn{2}{|c|}{1978} & \multicolumn{2}{|c|}{1979} & \multirow[b]{2}{*}{ ๆ $\uparrow: 0^{x} \sigma^{x}$} \\
\hline & $\mathrm{S}$ & A & Sp & $\mathrm{S}$ & A & $\mathrm{Sp}$ & \\
\hline \multicolumn{8}{|c|}{ Alderwood } \\
\hline C. glareolus & 78 & 192 & 40 & 87 & 181 & 23 & 0.8 \\
\hline A. flavicollis & 15 & 31 & 0 & 2 & 6 & 0 & 0.9 \\
\hline A. agrarius & 0 & 14 & 0 & $\overrightarrow{1}$ & 5 & 0 & 0.1 \\
\hline M. arvalis & 1 & 3 & 0 & 4 & 1 & 0 & 0.9 \\
\hline M. oeconomus & 0 & 1 & 0 & 2 & 1 & 1 & 0.3 \\
\hline M. agrestis & 1 & 13 & 5 & $\overrightarrow{5}$ & 1 & 5 & 0.6 \\
\hline M. musculus & 0 & 3 & 0 & 0 & 2 & 0 & 0.3 \\
\hline \multicolumn{8}{|c|}{ Pinewood } \\
\hline C. glareolus & 66 & 110 & 27 & 65 & 115 & 14 & 0.9 \\
\hline S. betulina & 0 & 0 & 0 & 0 & 0 & 1 & - \\
\hline A. flavicollis & 11 & 27 & 0 & 1 & 4 & 0 & 0.6 \\
\hline A. agrarius & 0 & 11 & 0 & 0 & 9 & 0 & 0.3 \\
\hline M. arvalis & 0 & 10 & 3 & 3 & 14 & 0 & 0.4 \\
\hline M. oeconomus & 1 & 1 & 0 & 0 & 0 & 0 & 1.0 \\
\hline M. agrestis & 3 & 24 & 19 & 15 & 9 & 3 & 0.8 \\
\hline M. musculus & 0 & 3 & 0 & 0 & 0 & 0 & 2.0 \\
\hline \multicolumn{8}{|c|}{ Willow brushwood } \\
\hline C. glareolus & 27 & 46 & 12 & 59 & 68 & 2 & 0.8 \\
\hline A. flavicollis & 4 & 31 & 0 & 0 & 4 & 0 & 0.6 \\
\hline A. agrarius & 0 & 55 & 0 & 0 & 38 & 0 & 0.3 \\
\hline M. arvalis & 0 & 2 & 2 & 1 & 4 & 0 & 0.1 \\
\hline M. oeconomus & 4 & 4 & 3 & 17 & 13 & 8 & 0.8 \\
\hline M. agrestis & 0 & 9 & 10 & 4 & 10 & 0 & 1.2 \\
\hline M. musculus & 0 & 4 & 0 & 1 & 2 & 0 & 0.4 \\
\hline \multicolumn{8}{|c|}{ Ash thicket } \\
\hline C. glareolus & 1 & 0 & 2 & 2 & 5 & 0 & 1.2 \\
\hline A. flavicollis & 1 & 2 & 0 & 0 & 1 & 0 & 1.0 \\
\hline A. agrarius & 0 & 10 & 0 & 0 & 5 & 0 & 0.9 \\
\hline M. arvalis & 0 & 2 & 1 & 0 & 5 & 0 & 1.0 \\
\hline M. oeconomus & 0 & 1 & 0 & 1 & 1 & 0 & 0.0 \\
\hline M. agrestis & 1 & 6 & 0 & 0 & 1 & 0 & 1.7 \\
\hline M. musculus & 0 & 1 & 0 & 0 & 1 & 0 & 0.0 \\
\hline
\end{tabular}

\section{RESULTS}

\subsection{Dynamics of Density}

No considerable disparities as regards dynamics of density in small rodent communities were observed in the alderwood, pine wood or willow brushwood areas. The increase of density from spring till autumn (numbers peak) was noted, followed by the decrease - from autumn till 
spring of the following year. The maximum animal densities in those biotopes (autumn 1977, 1978) varied, fluctuating from 63 to 85 rodents per 1 ha. (Fig. 2). In the ash thicket, no rodent density increase was observed from spring till summer 1978, and there were no captures in the spring of 1979. In autumn the rodent density in this biotope was almost by one third higher than in the three remaining biotopes (Fig. 2).

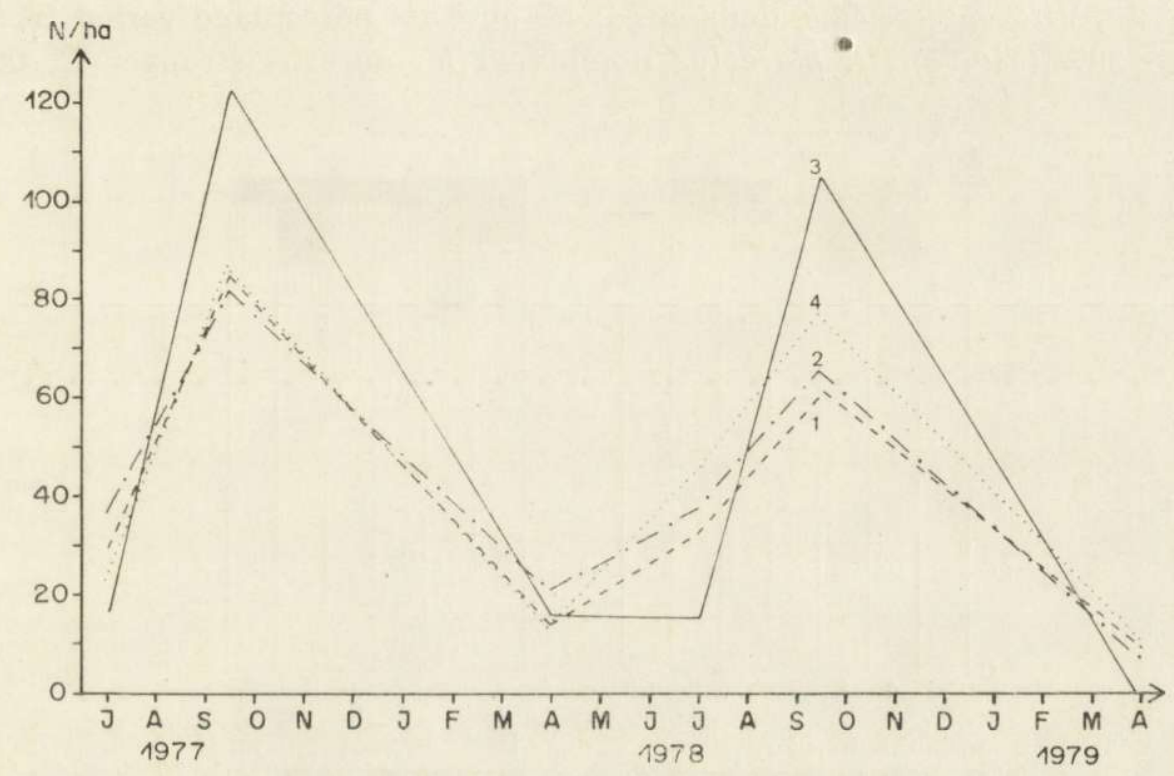

Fig. 2. Dynamics of density of small rodent communities in the habitats under study. 1 - alderwood, 2 - pine wood, 3 - ash thicket, 4 - willow brushwood.

\subsection{Species Composition and Dominance Structure in Small Rodent Communities}

Major disparities among rodent communities in different biotopes were due to the share of respective species in the given biotope, as well as to the length of time spent in it in successive seasons (Fig. 3).

From among the 7 species recorded in the alderwood, only two: C. glareolus and $M$. agrestis were present in this biotope in each of the seasons (Table 1). C. glareolus, whose percentage in this community varied from 75 to $92 \%$ in different seasons, was the dominant species here. M. agrestis percentage in respective seasons was considerably lower - from 0.5 to $17 \%$ (Fig. 3). The remaining species appeared in the alderwood periodically, making additions to the small rodent community in summer and autumn mainly. Among those, there were not only $M$. oeconomus, resident in the willow brushwood, but also A. flavicollis (max. 16\%) and A. agra- 
rius (max. 5\%), immigrating here from outside the study area (Table 1 , Fig. 3). The study of female to male ratio revealed that in the case of all the species captured in the alderwood.males were prevailing numerically (Table 1).

Of the 8 small rodent species recorded in the pine wood, C. glareolus and $M$. agrestis were constantly present in the biotope, as in the alderwood (Table 1). C. glareolus, with its percentage ranging from 55 to $82 \%$ in different seasons, dominated; $M$. agrestis percentage varied from 4 to $39 \%$ (Fig. 3). C. glareolus dominated $M$. agrestis stronger in the
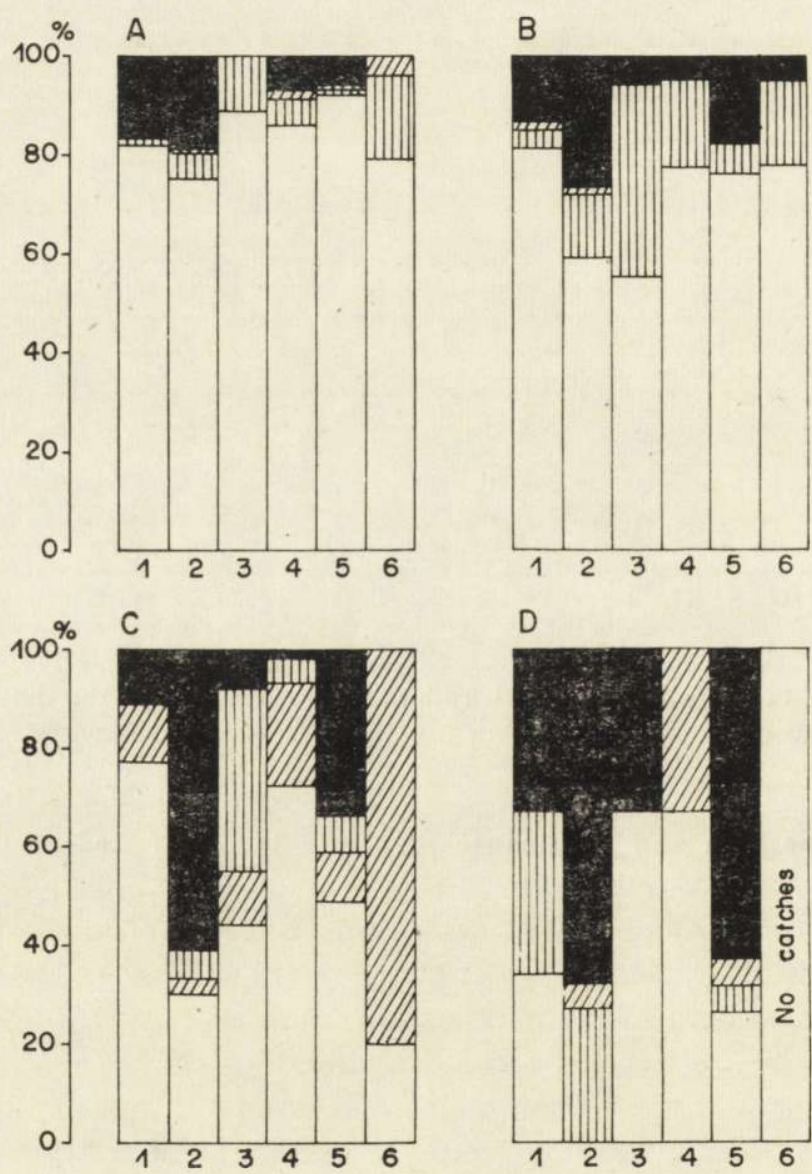

D-C.g. [I]

Fig. 3. Small rodent communities structure in the habitats under study. A alderwood, B - pine wood, C - willow brushwood, D - ash thicket, 1 - summer 1977, 2 - autumn 1977, 3 - spring 1978, 4 - summer 1978, 5 - autumn 1978 , 6 - spring 1979. 
alderwood than in the pine wood (difference significant statistically, $0.01<p<0.05$ ). The remaining species, temporarily dwelling in the pine wood, enriched this habitat's community in summer and autumn mainly. Among them, apart from the scarce $M$. oeconomus coming from the willow brushwood, there was a very numerous group consisting of species immigrating from other areas (Table 1, Fig. 3), with A. flavicollis, $A$. agrarius and $M$. arvalis, whose maximum percentages in the community amounted to 14,6 and $9 \%$ respectively. In the majority of species captured in the pine wood males prevailed numerically, with the only exception of $M$. musculus (Table 1).

From among the 7 rodent species recorded in the willow brushwood only two - C. glareolus and $M$. oeconomus - were resident in this biotope (Table 1). The percentage of C. glareolus in different seasons varied from 20 to $77 \%$, and this species was a dominant in the community only in four out of six seasons under study. M. oeconomus share ranged from 3 to $80 \%$ in various seasons; its numerical dominance increased considerably in the second year of the study, and this species took the dominant position in the spring of 1979, when C. glareolus percentage dropped (Table 1, Fig. 3).

M. agrestis was observed to appear seasonally in the willow brushwood (max. percentage - 37\%); it was resident in the adjacent alderwood and pine wood biotopes. Among the species migrating into the study area from outside $A$. flavicollis and $A$. agrarius were the most numerous, with percentages of 20 and $36 \%$ respecitvely (Table 1). Males numerical preponderance was observed among the majority of species captured in the willow brushwood, with the only exception of the $M$. agrestis population (Table 1).

The most variable rodent community was observed in the ash thicket. All species dwelled here temporarily, and the community composition changed rapidly from season to season (Table 1, Fig. 3). Transient individuals of $A$. flavicollis $(33 \%), A$. agrarius $(46 \%), M$. arvalis $(33 \%)$ and M. musculus $(5 \%)$ were the most numerous in the community. The remaining species captured in the ash thicket - C. glareolus, $M$. agrestis and $M$. oeconomus - were coming here from the adjacent biotopes. The study of spatial distribution of individual captures revealed that all C. glareolus specimens collected in the, ash thicket were captured in the other biotopes as well, during the same trapping series. Moreover, no one specimen of any species caught in the ash thicket in a given season remained in this biotope till the next season. The sex ratio index varied within different species captured in the ash thicket. Females prevailed among C. glareolus and $M$. agrestis, whereas $M$. oeconomus and M. musculus were represented by males exclusively (Table 1). 
In both years of the study, species composition in the small rodent community during the autumn peak of numbers and animal migration periods was the same in all of the biotopes under study, but the percentage of different species varied (Fig. 3). A significant correlation $(r=-0.888)$ was found between the autumn density peak among species migrating into the alderwood, pine wood and willow brushwood and the respective density peak among species resident in those biotopes, i.e. the dominant $C$. glareolus together with $M$. agrestis and $M$. oeconomus. C. glareolus density was especially relevant here - the higher it was, the lower the immigrating species density fell $(r=-0.887)$ (Fig. 4).

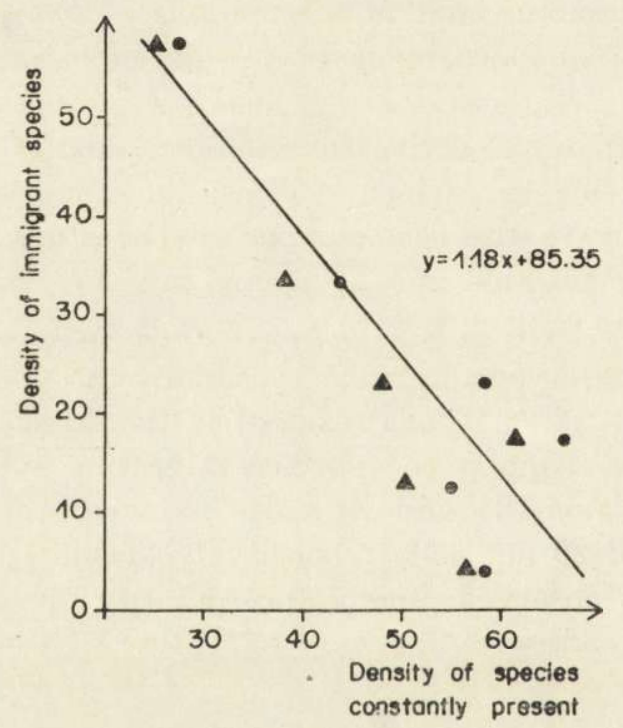

Fig. 4. Correlation between the autumn density of species resident in the alderwood, pine wood and willow brushwood and the density of species immigrating from other hiotopes. Dots - all species, $r=-0.888$, triangles $-C$. glareolus v. immigrants from other biotopes, $r=-0.887$.

The differences between the rodent communities in the four biotopes under study were compared by evaluating the Shannon-Wiener species diversity indexes (Cox, 1967) (Table 2). The index value increases as the number of species grows, and as the eveness component in the community increases (Table 1,2 ). The $\mathrm{H}$-index value was lowest in the alderwood rodent community (0.5-1.3), highest - in the ash thicket community $(0.9-2.4)$. This results from the strong domination of C. glareolus in the alderwood - in the ash thicket no species was found to have such a strong position (Table 1, Fig. 3).

The average number of captures - during a 10-day trapping series - 
per an individual of each species was studied, to the effect that C. glareolus was found to have the highest average - throughout the study 4.8 in the alderwood, 4.0 in the pine wood and 4.6 in the willow brushwood. Statistically, those figures are significantly higher (Student $t$-test $0.01<p<0.05$ ) than the respective figures evaluated for other species co-occurring with $C$. glareolus in the above mentioned biotopes. In the ash thicket, the average number of C. glareolus captures was 2.2, similar to the values calculated for other species in this habitat, but then significantly lower statistically (Student t-test, $0.01<p<0.05$ ) than the average number of $C$. glareolus captures in the alderwood, pine wood

Table 2

Absolute values of the Shannon-Wiener index of species diversity $(\mathrm{H}) ; \mathrm{n}-$ number of species.

\begin{tabular}{|c|c|c|c|c|c|c|c|c|c|c|c|c|}
\hline \multirow{3}{*}{ Habitat } & \multicolumn{4}{|c|}{1977} & \multicolumn{4}{|c|}{1978} & & & \multirow{2}{*}{\multicolumn{2}{|c|}{$\begin{array}{r}1979 \\
\text { Spring }\end{array}$}} \\
\hline & \multicolumn{2}{|c|}{ Summer } & \multicolumn{2}{|c|}{ Autumn } & \multicolumn{2}{|c|}{ Spring } & \multicolumn{2}{|c|}{ Summer } & \multicolumn{2}{|c|}{ Autumn } & & \\
\hline & $\mathrm{n}$ & $\mathrm{H}$ & $\mathrm{n}$ & $\mathrm{H}$ & $\mathrm{n}$ & $\mathrm{H}$ & $\mathrm{n}$ & $\mathrm{H}$ & $\mathrm{n}$ & $\mathrm{H}$ & $\mathrm{n}$ & $\mathrm{H}$ \\
\hline Alderw & 4 & 0.8 & 7 & 1.3 & 2 & 0.5 & 6 & 0.9 & 7 & 0.6 & 3 & 0.9 \\
\hline Pine wood & 4 & 0.9 & 7 & 1.8 & 3 & 1.3 & 4 & 1.0 & 5 & 1.2 & 2 & 0.9 \\
\hline Williw brhshwood & 3 & 1.0 & 7 & 2.1 & 4 & 1.7 & 5 & 1.2 & 7 & 2.0 & 2 & 0.7 \\
\hline Ash thicket & 3 & 1.6 & 6 & 2.1 & 2 & 0.9 & 2 & 0.9 & 7 & 2.4 & 0 & 0.0 \\
\hline
\end{tabular}

Table 3

Average number of captures per one individual in various biotopes.

\begin{tabular}{lcccc}
\hline Species & Alderwood & Pine wood & $\begin{array}{c}\text { Willow } \\
\text { brushwood }\end{array}$ & $\begin{array}{c}\text { Ash } \\
\text { thicket }\end{array}$ \\
\hline C. glareolus & 4.8 & 4.0 & 4.6 & 2.2 \\
A. flavicollis & 2.4 & 2.1 & 1.9 & 1.3 \\
A. agrarius, & 2.3 & 1.6 & 3.3 & 2.2 \\
M. arvalis & 1.3 & 1.3 & 1.4 & 1.3 \\
M. oeconomus & 1.2 & 1.0 & 2.1 & 1.7 \\
M. agrestis & 1.9 & 2.3 & 1.7 & 1.4 \\
M. musculus & 1.8 & 3.0 & 3.1 & 2.5 \\
\hline
\end{tabular}

and willow brushwood (Table 3). The low number of C. glareolus specimens captured in the ash thicket stems from the fact that this habitat formed only a part of this species local population range.

\subsection{Degree of Rodent Residency in a Habitat}

The distribution of places of capture of all rodents in each of the 10-day trapping series was studied, leading to the differentiation of specimens captured only in one habitat (i.e. those using one habitat only, 
later referred to as one-habitat) and the ones caught in two or more habitats (i.e. those using two or more habitats, later referred to as multihabitat). The number of multihabitat specimens of different species varied in the study area from season to season, being the highest in autumn and lowest in spring (Fig. 5).

The dynamics of numbers of multihabitat specimens correlated with the dynamics of rodent density (cf. Fig. 2 and 5). In the autumn of 1977 and 1978, during the highest density period in all the biotopes, the multihabitat specimens were coming from all the species present in the study area at that time (Table 1,4$)$. The study of the species composition

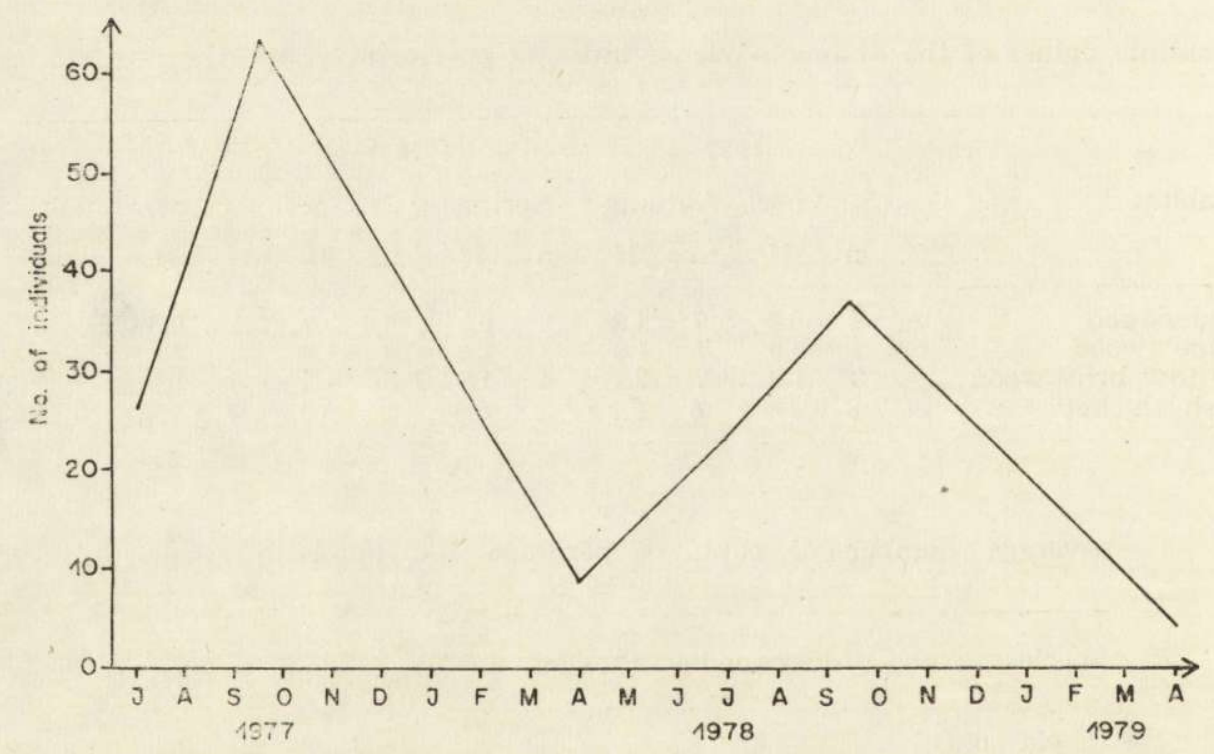

Fig. 5. Dynamics of numbers of multihabitat individuals - from all species occurring in the study area.

and the number of specimens using two or more habitats reveales that the autumn increase in numbers was caused chiefly by animals immigrating from outside the study area, A. flavicollis and A. agrarius in particular (Table 4, Fig. 5). C. glareolus constituted more than a half of multihabitat specimens from various species, being the only species the specimens of which were, throughout the six seasons, present in the group of animals using two or more habitats. The number of C. glareolus specimens in this group was stable from summer till autumn (Table 4).

The comparison of rodent communities from the four biotopes under study, in terms of the percentage of one-habitat individuals, revealed that the alderwood had the highest percentage of animals resident in 
the habitat $-86 \%$. A significantly lower percentage of one-habitat individuals was observed in the willow brushwood $(82 \%)$, and the lowest $-40 \%$ - in the ash thicket (difference significant at $0.01<p<0.05$ ) (Fig. 6).

Table 4

Numbers of multihabitat individuals - from different species - in the study area. Sp - spring, S - summer, A - autumn.

\begin{tabular}{|c|c|c|c|c|c|c|}
\hline \multirow{2}{*}{ Species } & \multicolumn{2}{|c|}{1977} & \multicolumn{3}{|c|}{1978} & \multirow{2}{*}{$\frac{1979}{\mathrm{Sp}}$} \\
\hline & $\mathrm{S}$ & A & $\mathrm{Sp}$ & $\mathrm{S}$ & A & \\
\hline C. glareolus & 20 & 18 & 6 & 21 & 18 & 4 \\
\hline A. flavicollis & 6 & 23 & 0 & 0 & 4 & 0 \\
\hline A. agrarius & 0 & 15 & 0 & 0 & 9 & 0 \\
\hline M. arvalis & 0 & 1 & 1 & 1 & 3 & 0 \\
\hline M. oeconomus & 0 & 2 & 0 & 1 & 1 & 0 \\
\hline M. agrestis & 0 & 2 & 2 & 0 & 1 & 0 \\
\hline M. musculus & 0 & 2 & 0 & 0 & 1 & 0 \\
\hline
\end{tabular}

In order to determine the degree of attachment of particular species to a habitat, as opposed to their share in the group of multihabitat individuals, we calculated - for each species - the average percentage of multihabitat individuals among all the specimens of the given species captured throughout the research (Fig. 7). M. agrestis was found to be the species most strongly attached to one habitat - the multihabitat individuals constituted only $3.5 \%$ of all the $M$. agrestis captured. The

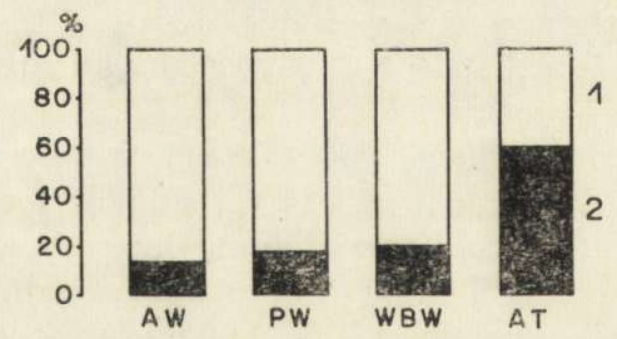

Fig. 6. Average percentage of one-habitat (1) and multihabitat (2) individuals in various biotopes. AW - alderwood, PW - pine wood, WBW - willow brushwood, $\mathrm{AT}$ - ash thicket.

murids appearing temporarily in the study area were the least attached - $24 \%$ of multihabitat individuals were noted among A. flavicollis, $18 \%$ - among $M$. musculus and 16\% - among A. agrarius. C. glareolus was somewhere in the middle of this range, with $7 \%$ of multihabitat 
individuals, i.e. the percentage significantly smaller than those of $A$. flavicollis and $A$. agrarius $(0.01<p<0.05)$.

As the study of the places of consecutive captures of multihabitat individuals shows, each specimen of this kind moved accross the boundary of two adjacent biotopes at an average of 2.1 times during each of the trapping series. The highest number of multihabitat individuals was recorded at the following boundaries: willow brushwood - pine wood (6.2 specimens per trap), willow brushwood - alderwood (5.8 specimens per trap), willow brushwood - ash thicket (5.0 specimens per trap), pine wood - alderwood (3.9 specimens per trap).

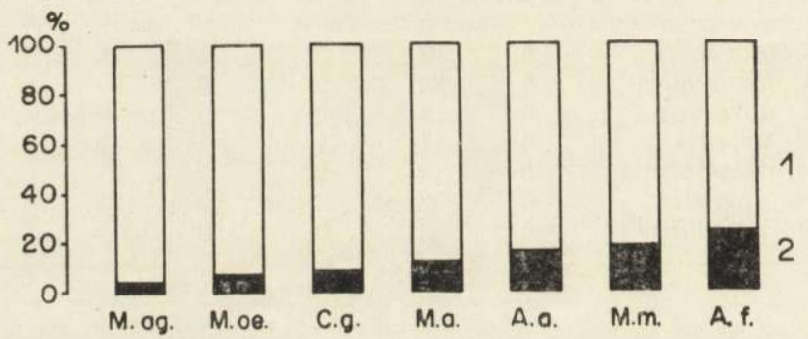

Fig. 7. Average percentage of one-habitat (1) and multihabitat (2) individuals in particular rodent species.

\section{DISCUSSION}

Regardless of phytosociological separateness of the alderwood, pine wood and willow brushwood biotopes the conditions for rodent dwelling (environment capacity) were very similar in all of them. Both the level and direction of seasonal rodent density changes in those three biotopes seem to support this statement.

A different density dynamics in the ash thicket was probably due to the fact that this environment was not suitable for the rodents to be inhabited permanently (small area, strong intermittent insolation, considerable temperature oscillation in the brushwood). The high rodent density during the autumn peak of numbers, presence of C. glareolus, $M$. agrestis and $M$. oeconomus (permanently resident in the adjacent, characteristic of them, biotopes), together with high percentages of A. flavicollis, A. agrarius, M. musculus and $M$. arvalis, all temporarily coming into this area from outside, indicate that the ash thicket, situated in the center of the complex, was a suitable place for the temporary retailment of the "surplus" of migrating animals. Such a rodent community was unstable and not permanent, which is also proved by a very variable species composition, the Shannon-Wiener index value and high 
percentages of multihabitat individuals. Taking into consideration, however, the significance of animal dispersal in the abundance control among numerous populations (Lidicker, 1962; Anderson, 1970; Birch, 1971 based on Petrusewcz, 1978; Kozakiewicz \& Kozakiewicz, 1975; Łomnicki, 1978; Tamarin, 1980) and the possibility of emigrants surviving in environments non-typical of them (Hansson, 1977a, 1977b), it seems that the presence of the ash thicket in the complex under study created greater chances for rodent survival in the area.

In spite of similar densities, rodent communities in the alderwood, pine wood and willow brushwood differed as regards the species share, especially of those resident in a given biotope, and those appearing there temporarily. It seems that the percentage of the transient species depended on the features created in the community by the species permanently present in the habitat, particularly by the abundance of C. glareolus. In the alderwood, for instance, where C. glareolus prevailed over M. agrestis much stronger than in the pine wood, the immigrants percentage was lower than in the pine wood complex. Similar relationship was revealed in the willow brushwood rodent community, where C. glareolus was more abundant than $M$. oeconomus, second resident species, muah weaker than in the alderwood and pine wood. At the same time, the percentage of species coming to this community from outside the study area and the adjacent habitats was higher than in the pine wood and alderwood complexes (cf. Fig. 4). The structure of the ash thicket rodent community also seems to be a proof of such a relationship.

The permanent presence and abundance of $C$. glareolus in the alderwood and willow brushwood proves the eurhybiontic character of this species. Various authors have discussed that (Aulak, 1970; Pucek, 1983; Mazurkiewicz, 1984) stressing also the high food tolerance of these voles (Banach et al., 1980; Jensen, 1982; Gębczyńska, 1983). In encounters with other rodents $C$. glareolus often exhibits a retreating attitude (avoidance) (Andrzejewski \& Olszewski, 1963; Kalinowska, 1971; Kołodziej et al., 1972; Chełkowska et al., 1985). The results of this work prove that this species can, when inhabiting permanently biotopes most favourable to it, dominate species seasonally migrating into those biotopes and control their abundance.

The seasonal richness of a rodent community resulted from the animal migration processes, and depended on the species composition in adjacent habitats communities as well as on the migration tendencies of A. flavicollis, A. agrarius and $M$. musculus, numerous in the agricultural and woodland countryside of this part of the Mazurian Lake Districs. A similarly rich rodent community was found by Aulak (1970) in various biotopes in the Białowieża National Park. Rodent communities in Polish 
less natural forest complexes are not so diverse. In pine monocultures, for instance, it is very seldom that more than four species can be found (Banach et al., 1979; Banach et al., 1980; Mazurkiewicz, 1984). Common boundaries between different forest biotopes can then enrich rodent communities with additional species.

The customary applied criteria of distinguishing one- and multihabitat individuals do not allow the ecological status of the multihabitat individuals to be unequivocally determined. This group could include interhabitat migrants as well as individuals of extended home ranges, and hence resident in areas comprising parts of various biotopes. In this study, the high percentage of multihabitat animals in the ash thicket was also due to the abundance of species immigrating from outside the study area. Therefore, the size and quality of a biotope together with the species structure of the community resulting from the biotope's character can determine the abundance of multihabitat animals.

The above presented studies reveal that a rodent community inhabiting a forest complex of a patchy character can differ in particular parts of the complex. A high degree of patchiness may appear a factor enhancing wide distribution and substantial overlap of ranges in forest rodent species. As a consequence, patchiness can be regarded as promoting enrichment of local rodent faunas in forest ecosystems. It creates also the possibility of emergance of different specimen categories within the same species. It can therefore complicate the competitive networks in small rodent communities and have a stabilizing influence on ecological systems in different environments, integrating them at the same time.

Acknowledgements: The author wishes to express her gratitude to Prof. Z. Podbielkowski and Dr. H. Tomaszewicz for the phytosociological description of the biotopes under study.

\section{REFERENCES}

1. Anderson P. K., 1970: Ecological structure and gene flow in small mammals. Symp. Zool. Soc., London, 26: 299-325.

2. Andrzejewski R. \& Olszewski I., 1963: Social behaviour and interspecific relations in Apodemus flavicollis (Melchior 1834) and Clethrionomys glareolus (Schreber 1780). Acta theriol., 7: 155-168.

3. Aulak W., 1970: Small mammal communities of the Białowieża National Park. Acta theriol., 15: 465-515.

4. Banach A., Kozakiewicz A., Kozakiewicz M. \& Szulc M., 1979: Stabilizing role of zoocoenosis enrichment and the ways of animal immigrations into ecosystems Memorabilia zool., 32: 49-56.

5. Banach A., Kozakiewicz A. \& Kozakiewicz M., 1980: Tentative comparison of small mammal communities in a poor pine stand of various age. Bull. Acad. pol. Sci., Cl. II, 28: 1/2: $43-48$. 
6. Chelkowska H., Walkowa W. \& Adamczyk K., 1985: Spatial relationships in sympatric populations of the rodents: Clethrionomys glareolus, Microtus agrestis and Apodemus agrarius. Acta theriol., 30: 51-78.

7. Cox G. W., 1967: Laboratory manual of general ecology. Dubuque: 1-165, Iowa.

8. Fretwell S. D., 1972: Populations in a seasonal environment. Princenton Univ. Press: 1-217 Princeton, New Jersey.

9. Fretwell S. D. \& Lucas H. L. Jr., 1969: On territorial behaviour and other factors influencing habitat distribution in birds. I. Theoretical development. Acta Biotheor., 19: 16-36.

10. Gębczyńska Z., 1983: Feeding habits. [In: Ecology of the bank vole, Ed. K. Petrusewicz]. Acta theriol., 28, Suppl. 1: $40-49$.

11. Goertz J. W., 1964: The influence of habitat quality upon density of cotton rat population. Ecol. Monogr., 34: 359-381.

12. Hansson L., 1977a: Spatial dynamics of field voles, Microtus agrestis, in heterogenous landscape. Oikos, 29: 539-544.

13. Hansson L., 1977b: Landscape ecology and stability of populations. Landscape Plann., 4: 85-93.

14. Hansson L., 1979: On the importance of landscape heterogeneity in northern regions for the breeding population densities of homeotherms: a general hypothesis. Oikos, 33: 182-189.

15. Jensen T. S., 1982: Habitat distribution, home range and movements of rodents in mature forest and reforestation. Abstracts of papers. Third Intern. Theriol. Congress, Helsinki: 116.

16. Kalinowska A., 1971: Trapping of Apodemus flavicollis and Clethrionomys glareolus in double traps. Acta theriol., 16: 73-78.

17. Kołodziej A., Pomianowska I. \& Rajska E., 1972: Differentiation of contacts between specimen in a Clethrionomys glareolus population. Bull. Acad. pol. Sci. Cl. II, 20: 97-102.

18. Kozakiewicz M. \& Kozakiewicz A., 1975: Rola migracji w ekologicznej strukturze i organizacji populacji. Wiad. ekol., 21: 187-200.

19. Lidicker W. Z. Jr., 1962: Emigration as a possible mechanism permitting the regulation of population density below carrying capacity. Am. Nat., 96: 29-33.

20. Łomnicki A., 1978: Individual differences between animals and the natural regulation of their numbers. J. Anim. Ecol., 47: 461-475.

21. Mazurkiewicz M., 1984: Population density of small rodents as affected by chosen elements of tree stand structure. Bull. Acad. pol. Sci. Cl., II, 32: 209-217.

22. Petrusewicz K., 1978: Osobnik, populacja, gatunek. PWN: 1-384, Warszawa.

23. Pucek M., 1983: Habitat preference. [In: Ecology of the bank vole, Ed. K. Petrusewicz]. Acta theriol., 28, Suppl. 1: $31-40$.

24. Pucek Z., 1969: Trap response and estimation of numbers of shrew in removal catches. Acta theriol., 14: 403-426.

25. Rottenbery J. T. \& Wiens J. A., 1976: A method for estimating species dispersion from transect data. Am. Midl. Nat., 94: 64-78.

26. Tamarin R, H., 1980: Dispersal and population regulation in rodents. [In: Biosocial mechanisms of population regulation, Ed. Cohen M. N., Malpass R. S. \& Klein H. G.]. Yale Univ. Press: 117-134, New Haven, London.

Received 12 June 1985, Accepted 20 February 1987. 


\section{Anna BANACH}

\section{ZESPOEY DROBNYCH GRYZONI W KOMPLEKSIE BIOTOPOW LESNYCH}

\section{Streszczenie}

W pracy podjęto próbę oceny wpływu mozaiki środowisk leśnych na strukturę zespołu drobnych gryzoni oraz na sposób wykorzystania takiego środowiska przez gryzonie. Teren badań na Pojezierzu Mazurskim o calkowitej powierzchni 7,17 ha obejmowal cztery sąsiadujące ze sobą biotopy leśne: lęg olszowy, las sosnowy, zarośla lozowe, młodnik jesionowy oraz ich wspólne granice (Ryc. 1). Zwierzęta łowiono w pułapki żywołowne w dziesięciodniowych seriach połowów od lata 1977 roku do wiosny 1979 roku (w sumie 6 sezonów badawczych). Zastosowano metodę CMR.

W każdym z czterech biotopów stwierdzono okresowe (jesień) występowanie siedmiu tych samych gatunków drobnych gryzoni (Tabela 1). Różnice pomiędzy zespołami gryzoni badanych biotopów wynikały z różnego udziału poszczegclnych gatunków w zespołach $\mathrm{w}$ kolejnych sezonach a więc $\mathrm{z}$ ich pozycji w hierarchii dominacyjnej i długości okresu przybywania w biotopie (Tabela 1 i 2, Ryc. 3).

W skład zespołu gryzoni łęgu olszowego, lasu sosnowego i zarośli łozowych wchodziły trzy grupy gatunków: 1. gatunki stale w nim obecne (nornica ruda i nornik bury lub nornik północny), 2. gatunki okresowo nachodzące z sąsiednich biotopów, 3. gatunki imigrujące $\mathrm{z}$ terenów położonych poza powierzchnią badawczą (Tabela 1, Ryc. 3). W młodniku jesionowym rejestrowano wyłącznie gatunki nachodzące $\mathrm{z}$ innych środowisk - żaden gatunek nie osiedlał się w tym biotopie na stałe (Tabela 1, Ryc. 3). Udział w zespołach gatunków okresowo nachodzących z innych środowisk zależał od pozycji dominacyjnej nornicy rudej (Ryc. 3,4).

W każdym zespole gryzoni i w obrębie każdego gatunku wyodrębniono osobniki jedno- $\mathrm{i}$ wielośrodowiskowe. $\mathrm{Na}$ tej podstawie oceniono stopień przywiązania poszczególnych zespołów i gatunków do jednego biotopu (Ryc. 6 i 7). Stwierdzono, że liczba gryzoni wielośrodowiskowych na powierzchni badawczej najmniejsza była wiosną a największa - jesienią (szozyt liczebności i dyspersji gryzoni) w obu latach badań (Tabela 4, Ryc. 5).

Podkreślono, że sąsiedztwo różnych biotopów wzbogaca poszczególne zespoły gryzoni w dodatkowe gatunki, umożliwia osobnikom korzystanie $\mathrm{z}$ więcej niż jednego środowiska a przez to - utrzymanie kontaktu pomiędzy gryzoniami różnych środowisk. Zwrócono także uwagę na istotną rolę młodnika jako środowiska suboptymalnego dla gryzoni leśnych, w którym przechowywany jest „nadmiar” zwierząt pochodzących z różnych środowisk, zwłaszcza w okresie szczytu liczebności i dyspersji zwierząt. 